$\xi_{p}$

\title{
A Systematic Review of Individuals' Acceptance of IOT-based Technologies
}

\author{
Gamal Abdulnaser Alkawsi ${ }^{1 *}$, Nor'ashikin Bte. Ali ${ }^{2}$ \\ *Corresponding author E-mail:jamalmail@gmail.com
}

\begin{abstract}
This paper primarily aims to provide a systematic review of factors influencing the individuals' acceptance of Internet of things (IoT). There are numerous studies in literature that examine factors affecting technology acceptance. However, the studies on the review for acceptance of Internet of Things is limited. This study conducted a review and analysis of 32 articles from academic journals and conference proceedings published about the adoption, acceptance and diffusion of IoT. According to the review outcome, there are increasing numbers of studies that have been conducted in the IoT acceptance among individuals hailing from various points of view, with different factors affecting such viewpoints. Nevertheless, it was also noted that a theoretical, methodological and empirical study has yet to be carried out in the field to determine the factors related to the context of its application. The findings also led the author to recommend more future theoretical, methodological and empirical research to be conducted on the topic.
\end{abstract}

Keywords: Internet of things, smart meters, acceptance, individuals.

\section{Introduction}

The information revolution and the increasing IT use has led to the proliferation of utilization of technology like mobile applications, online services and automated services and hence, increase people's dependence on them in their daily lives. As a consequence, this has brought about the development of related innovative services like smart cars, smart homes and smart cities, aided by the Internet capabilities, allowing every object to be connected to a network. Such synergistic service is referred to as the Internet of Things (IoT) and it encapsulates the IT components of hardware, software and networks - a combination that leads to a robust base that can be used as a service innovation platform. More importantly, this technology allows Internet to disseminate into the actual realm of physical objects to develop a group of interlined devices in a form of global infrastructure, in which there is direct communication among sensors, machines, appliances and wearable devices online. Industries are rife with the applications of IoT and this holds true in the case of healthcare, power management, agriculture, urban management and industrial control.

The purpose of IoT is to make a difference in our lives in terms of allowing various applications to function throughout industries and markets, and boosting technology and innovative services growth. On a global scale, majority of countries expect to reap the promises brought on by smart cities that focus on power, building and transportation. In a related study,(1), such expectation indicates greater levels of economic contribution as high as 54\%, along with an approximate market potential of around U.S.\$392.94 billion. However, despite its appealing advantages, many industries have been facing barriers to IoT adoption, thereby slowing down its adoption rate (2-4). More specifically, according to (5) the IoT value largely hinges on the individuals, firms and governments acceptance of it, all affected by the perceptions of the public about the related pros and cons. This indicates that the involvement and acceptance of individuals count when it comes to
IoT adoption; otherwise technology will most likely be ignored. Therefore, obtaining information on the understanding of individuals of IoT plays a key role in the development and introduction of successful applications implementations and acceptance.

Regardless of its advantages for individuals, IoT raises serious ethical, economic, and technical issues. Notably, extant literature places greater stress on the technical issues of IoT and less attention to the issues faced by individuals in their usage of IoT-based services (6). Further, most of the IoT current studies mainly addressed its architecture, design and implementation from the perspective of technology (e.g.(7-11) ). Meanwhile, other authors laid emphasis on providing a discussion of IoT among individuals either investigated IoT in general, which is not precise where different IoT technologies have different properties and functions. Moreover, in-depth researches were carried out on the issues of IoT acceptance among individuals are few, there is a lack of indepth studies about specific IoT-based technologies and services (6). Hence, in this study, a systematic review of existing literature dedicated to IoT acceptance is conducted to determine the significant issues touched upon by the studies, and identify the underresearched areas, based on which, avenues for future IS research to pursue are recommended.

This paper is organized as follows; Section 2 explains the research method, search processes and the schema of data extraction. This is followed by section 3 that contains the findings and discussions and section 4 that enumerates the future research implications. Finally, section 5 concludes the review.

\section{Research Method}

Internet of things (IoT) is considered to be a novel phenomenon that has recently been introduced. In this study, a systematic review of literature on the topic is carried out to shed light on the current Information Systems (IS) research state in terms of the issues faced in adopting IoT. This study makes use of online data- 
base searchers as the main literature gathering method, following IS researchers trend of doing so, particularly those who are keen to explore contemporary phenomenal issues $(15,16)$. The study is guided by the basic writing of systematic review in IS studies, specifically exemplified by (17) and (15). This review's contextual boundary is individual users rather than organization users, and the significant issues that arise prior to their adoption of IoTbased applications and services. With regards to the temporal review boundary, it covers published articles in prior years up until April 2018

\subsection{Search Process}

The review process entails exploring five quality scholarly literature databases namely ScienceDirect, IEEE Xplore, Scopus, Taylors \& Francis and Google Scholar. This is because according to (15) the above mentioned databases pave access to top IS journals, with high-quality peer-reviewed IS conference publications. Researchers of this caliber make use of key terms like adoption, acceptance and diffusion of technology, in an interchanging manner to present positive implementation decisions of contemporary technologies (18) and hence, the key terms (IoT, adopt, accept and diffuse) were used for searching the five databases. The scope of the search was limited to the article's title or document's title to ensure articles relevance.

Table 1: Search results of literatures databases

\begin{tabular}{|c|c|c|c|}
\hline \multirow{2}{*}{$\begin{array}{l}\text { Literatures } \\
\text { Database }\end{array}$} & \multirow[b]{2}{*}{ Search Keywords } & \multirow[b]{2}{*}{ Look-in } & \multirow[b]{2}{*}{$\begin{array}{c}\text { Search } \\
\text { result }\end{array}$} \\
\hline & & & \\
\hline \multirow{3}{*}{$\begin{array}{l}\text { ScienceDirect } \\
\text { (Elsevier) }\end{array}$} & $\begin{array}{l}\text { TITLE ("Internet of things ") } \\
\text { and TITLE (adopt*) }\end{array}$ & \multirow{3}{*}{ Title } & 4 \\
\hline & $\begin{array}{l}\text { TITLE("Internet of things ") and } \\
\text { TITLE(accept*) }\end{array}$ & & 0 \\
\hline & $\begin{array}{l}\text { TITLE("Internet of things ") and } \\
\text { TITLE(diffuse*) }\end{array}$ & & 0 \\
\hline \multirow{3}{*}{ IEEE Explore } & $\begin{array}{l}\text { (("Document Title":" Internet of } \\
\text { things ") AND "Document Ti- } \\
\text { tle":"adopt*") }\end{array}$ & \multirow{3}{*}{$\begin{array}{l}\text { Document } \\
\text { Title }\end{array}$} & 7 \\
\hline & $\begin{array}{l}\text { (("Document Title":" Internet of } \\
\text { things ") AND "Document Ti- } \\
\text { tle":"accept*") }\end{array}$ & & 3 \\
\hline & $\begin{array}{l}\text { (("Document Title":" Internet of } \\
\text { things ") AND "Document Ti- } \\
\text { tle":"diffuse*") }\end{array}$ & & 0 \\
\hline \multirow{3}{*}{ Scopus } & $\begin{array}{l}\text { TITLE(Internet of things) AND } \\
\text { TITLE(adopt*) }\end{array}$ & \multirow{3}{*}{ Title } & 33 \\
\hline & $\begin{array}{l}\text { TITLE(Internet of things) AND } \\
\text { TITLE(accept*) }\end{array}$ & & 4 \\
\hline & $\begin{array}{l}\text { TITLE(Internet of things) AND } \\
\text { TITLE(diffuse*) }\end{array}$ & & 0 \\
\hline \multirow{3}{*}{$\begin{array}{l}\text { Taylors \& } \\
\text { Francis }\end{array}$} & $\begin{array}{l}\text { title: " Internet of things" AND } \\
\text { title: adopt* }\end{array}$ & \multirow{3}{*}{ Title } & 3 \\
\hline & $\begin{array}{l}\text { title: " Internet of things" AND } \\
\text { title: accept* }\end{array}$ & & 0 \\
\hline & $\begin{array}{l}\text { title: " Internet of things" AND } \\
\text { title: diffuse* }\end{array}$ & & 0 \\
\hline \multirow{3}{*}{$\begin{array}{l}\text { Google } \\
\text { Scholar }\end{array}$} & $\begin{array}{l}\text { allintitle: Internet of things } \\
\text { "adoption" OR "adopt" }\end{array}$ & \multirow{3}{*}{$\begin{array}{l}\text { Title of } \\
\text { article }\end{array}$} & 52 \\
\hline & $\begin{array}{l}\text { allintitle: Internet of things "ac- } \\
\text { ceptance" OR "accept" }\end{array}$ & & 17 \\
\hline & $\begin{array}{l}\text { allintitle: Internet of things "dif- } \\
\text { fusion" OR "diffuse" }\end{array}$ & & 14 \\
\hline Total & & & 137 \\
\hline
\end{tabular}

In the initial search, 137 articles (see Table 1), representing IoTbased applications and services (e.g., electronic toll collection, smart devices, early warning systems Internet of Medical Things and IoT retail services) that did not entail the application of smart meters that form the part and parcel of the IoT applications and services. Hence, the author carried out another search to reinforce the first one, where the term IoT was replaced with smart meters.
An additional 29 articles related to the latter term were produced by the five databases making a total sum of 166 articles.

After confirming for articles duplication, it was revealed that 74 articles were duplicated, with the high number of duplication attributed to the common databases (e.g., Google Scholar and Scopus).

In the second step of the search process, the pool of articles was filtered using practical screening. In this step, the articles abstracts were scanned for the significance of their relevance to the study context (17) and (15). Such filtering aimed to exclude general concept articles, technical articles, articles written in other than the English language, articles dedicate do the organizational perspective, periodical articles published by news websites, trade journals and magazines. After such screening and filtering processes, 60 articles were dropped from the list, as a result of which, only 32 articles remained for the process of data extraction.

\subsection{Data Extraction}

The data-extracted from articles are used for the purpose of addressing and achieving the aim of the review. Several top theories and models have been used to examine the adoption nature of innovation among individuals and majority of reviews conducted on new technologies adoption and acceptance have adopted such models and theories, aiming to examine technology adoption and diffusion in various cases. The reviews showed an enriching, diverse body of theoretical and empirical work in light of adoption and diffusion of innovations. This shows that research methods, theories, models, constructs, type of applications, usage stage, empirical work and context are all employed to extract data to achieve the purpose of IoT adoption and acceptance analysis and recommending avenues for future studies. In articles devoid of the methodology section, the review is related to such articles conceptual concept.

\section{Findings}

The outcome of the process of data extraction were reflected from various aspects including articles distribution throughout the years, outlets of publication, adopted theories/models, type of applications, the usage stage and the acceptance factors of IoT.

The distribution of articles throughout the years are presented in Figure 1 and from the figure, it is clear that there are no related articles published prior to 2010, while the number of articles showed an increase in 2016 to 12 articles. This particular growth could be a validation of the IoT adoption and acceptance research area. Nevertheless, the two published articles in the present year (2018) lack a complete picture of research attempts conducted throughout the year (until April 2018).

12

10

8

6

4

2

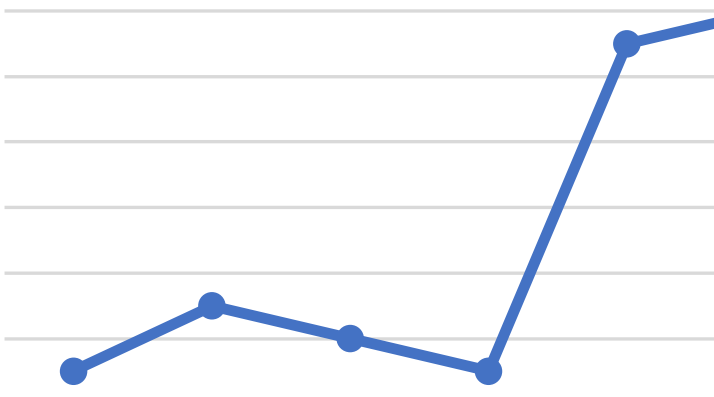

Fig. 1: Distribution of articles over years 
Following an analysis of the publication outlets of the articles, the findings indicated that majority of the articles (17 articles) originated from journals, whereas the several remaining ones (14 articles) originated from conferences, one from a book. Tables 3 and 4 tabulate that only a single article (19) came from the Journal of the Association of Information Systems, as majority of the articles have yet to be appended to top IS journals and conferences, identified by the Association for Information Systems (AIS) like MISQ, ISR and EJIS journals or conferences including ICIS, AMCIS and PACIS.

Table 2: Distribution of Articles by Journals \begin{tabular}{|l|c|c|}
\hline Journal & Article & Publications \\
\hline
\end{tabular}

\begin{tabular}{|l|c|c|}
\hline \multicolumn{1}{|c|}{ Journal } & Article & Publications \\
\hline Indian Journal of Science and Technology & $(20)$ & 1 \\
\hline $\begin{array}{l}\text { Asia Pacific Journal of Marketing and Lo- } \\
\text { gistics }\end{array}$ & $(21)$ & 1 \\
\hline Journal of Computer Information Systems & $(22)$ & 1 \\
\hline $\begin{array}{l}\text { International Journal of Software Engineer- } \\
\text { ing and Its Applications }\end{array}$ & $(23)$ & 1 \\
\hline $\begin{array}{l}\text { International Journal of Information Man- } \\
\text { agement }\end{array}$ & $(24)$ & 1 \\
\hline International Journal of Applied Research & $(25)$ & 1 \\
\hline Computer in Human behavior & $(26)$ & 1 \\
\hline IEEE Internet of Things Journal & $(27)$ & 1 \\
\hline $\begin{array}{l}\text { Journal of Science and Technology (Per- } \\
\text { tanika) }\end{array}$ & $(28)$ & 1 \\
\hline $\begin{array}{l}\text { The international journal of cybernetics, } \\
\text { systems and management sciences (Kyber- } \\
\text { netes) }\end{array}$ & $(29)$ & 1 \\
\hline $\begin{array}{l}\text { Global Business and Management Research: } \\
\text { An International Journal }\end{array}$ & $(30)$ & 1 \\
\hline $\begin{array}{l}\text { Journal of Fundamental and Applied Sci- } \\
\text { ences }\end{array}$ & $(31)$ & 1 \\
\hline Internet Research Journal & $(32)$ & 1 \\
\hline Applied Energy Journal & $(33)$ & 1 \\
\hline Energy Research \& Social Science Journal & $(34)$ & 1 \\
\hline $\begin{array}{l}\text { Journal of the Association of Information } \\
\text { Systems }\end{array}$ & $(19)$ & $(35)$ \\
\hline $\begin{array}{l}\text { Behaviour \& Information Technology Jour- } \\
\text { nal }\end{array}$ & & 1 \\
\hline & & 1 \\
\hline
\end{tabular}

Table 3: Distribution of Articles by Conferences

$$
\text { Conference }
$$

IEEE International Conference on Green Computing and Communications

PTC's annual conference

45th Annual Conference of the European Marketing Academy (EMAC)

6th International Conference on Smart Computing and Communications, ICSCC 2017

1st International Conference on Next Gen-

eration Computing Applications (NextComp)

\begin{tabular}{|c|c|}
\hline Article & Publications \\
\hline$(36)$ & 1 \\
\hline (37) & 1 \\
\hline (38) & 1 \\
\hline (39) & 1 \\
\hline (40) & 1 \\
\hline (41) & 1 \\
\hline (42) & 1 \\
\hline (43) & 1 \\
\hline (44) & 1 \\
\hline (45) & 1 \\
\hline (46) & 1 \\
\hline (47) & 1 \\
\hline (48) & 1 \\
\hline (49) & 1 \\
\hline
\end{tabular}

\section{Total}

The review of the 32 articles are categorized further according to theory/ framework/model used in each article. In some studies related concepts of costs, security, risks, benefits, and the like are discussed and were thus categorized under 'general concepts'.

In Table 4, various theories and models utilized to shed insight into the IoT acceptance factors are tabulated into categories, and notably, majority of the articles tested theories through empirical field data. Six articles were categorized under 'general concepts' that explained IoT acceptance factors.

The extensively utilized model, among other models in the reviewed studies, is the Technology Acceptance Model (TAM), after which the Unified Theory of Acceptance and Use of Technology (UTAUT) comes next. Moreover, most of the articles (29 articles) empirically tested theories/frameworks/ models, while 3 articles did not. Also, only a few articles adopted a combination of multiple theoretical perspectives to shed light on the IoT acceptance factors, indicating that multifaceted nature of the IoT phenomenon. In addition, although majority of the articles adopted theories and models to determine the factors affecting the IoT acceptance, there is still lack of theories demonstrating the way individuals respond differently rather than similarly to some factors.

Table 4: Use of theory by reviewed articles

\begin{tabular}{|c|c|c|c|c|}
\hline & $\begin{array}{c}\text { Theory(T) } \\
\text { /Framework(F) } \\
\text { /Model }(\mathrm{M})\end{array}$ & $\begin{array}{l}\text { (Empirical } \\
\text { Testing) }\end{array}$ & $\begin{array}{c}\text { (No } \\
\text { Empirical } \\
\text { Testing) }\end{array}$ & Frequency \\
\hline (M) & $\begin{array}{l}\text { Technology Ac- } \\
\text { ceptance Model } \\
\text { (TAM) }\end{array}$ & $\begin{array}{c}(21)(37)(22)(24) \\
(38)(41)(50)(27) \\
(44)(28)(29)(51) \\
(34)(48)(49) \\
(36)\end{array}$ & (25) & 17 \\
\hline$(\mathrm{T})$ & $\begin{array}{l}\text { Unified Theory of } \\
\text { Acceptance and } \\
\text { Use of Technology } \\
\text { (UTAUT) }\end{array}$ & $(43)(30)(45)$ & (25) & 4 \\
\hline$(\mathrm{T})$ & $\begin{array}{l}\text { Extended Unified } \\
\text { Theory of Accep- } \\
\text { tance and Use of } \\
\text { Technology } \\
\text { (UTAUT2) }\end{array}$ & (46) & & 1 \\
\hline$(\mathrm{T})$ & $\begin{array}{c}\text { Technology para- } \\
\text { dox Theory }\end{array}$ & (23) & & 1 \\
\hline$(\mathrm{T})$ & Dual-factor Theory & (23) & & 1 \\
\hline (M) & $\begin{array}{l}\text { Value- based } \\
\text { Adoption model } \\
\text { (VAM). }\end{array}$ & (22) & & 1 \\
\hline$(\mathrm{T})$ & $\begin{array}{l}\text { Theory of Rea- } \\
\text { soned Action } \\
\text { (TRA) }\end{array}$ & (24) & & 1 \\
\hline$(\mathrm{T})$ & $\begin{array}{l}\text { Theory Planned } \\
\text { Behavior (TPB) }\end{array}$ & $(24)(48)$ & & 2 \\
\hline$(\mathrm{T})$ & $\begin{array}{l}\text { Innovation Diffu- } \\
\text { sion Theory (IDT) }\end{array}$ & (29) & & 1 \\
\hline (M) & $\begin{array}{l}\text { Technological } \\
\text { Innovativeness } \\
\text { (TI) } \\
\end{array}$ & (29) & & 1 \\
\hline$(\mathrm{T})$ & $\begin{array}{c}\text { Privacy Calculus } \\
\text { Theory }\end{array}$ & (29) & & 1 \\
\hline$(\mathrm{T})$ & $\begin{array}{c}\text { Protection Motiva- } \\
\text { tion Theory }\end{array}$ & (29) & & 1 \\
\hline (M) & $\begin{array}{c}\text { Delone and } \\
\text { McLean IS success } \\
\text { model }\end{array}$ & (32) & & 1 \\
\hline$(\mathrm{T})$ & $\begin{array}{l}\text { Innovation Diffu- } \\
\text { sion Theory (IDT) }\end{array}$ & (45) & & 1 \\
\hline (T) & $\begin{array}{l}\text { Protection Motiva- } \\
\text { tion Theory (PMT) }\end{array}$ & (35) & & 1 \\
\hline$(\mathrm{T})$ & $\begin{array}{l}\text { Organismic Inte- } \\
\text { gration Theory }\end{array}$ & (48) & & 1 \\
\hline$(\mathrm{T})$ & Domestication of & (36) & & 1 \\
\hline
\end{tabular}




\begin{tabular}{|c|c|c|c|c|}
\hline & Technology & & & 1 \\
\hline (M) & $\begin{array}{c}\text { Network external- } \\
\text { ities Model }\end{array}$ & $(26)$ & $(26)$ & 1 \\
\hline (F) & $\begin{array}{c}\text { Concerns for In- } \\
\text { formation Pri- } \\
\text { vacy (CFIP) }\end{array}$ & $\begin{array}{c}(19,20,31), \\
(40),(52)\end{array}$ & $\begin{array}{c}(47), \\
(39)\end{array}$ & 6 \\
\hline \multicolumn{2}{|c|}{$\begin{array}{c}\text { General Concepts } \\
\text { Total (without repeti- } \\
\text { tions) }\end{array}$} & $\mathbf{2 9}$ & $\mathbf{3}$ & \\
\hline
\end{tabular}

Table 5 presents the 32 articles contextualized into technology (smart homes, smart city, smart meters, etc.) and study locations. The table also provides the number of articles $(\mathrm{N})$ per technology context and location. Based on the findings, majority of the articles concentrated on IoT technology in general (11 articles), with other ( 9 articles), concentrated on smart meter technology. The findings also indicate that only a few articles touched upon other IoT technologies. Further, the findings show slight number of articles appeared in different countries, which implies that IoT adoption and acceptance literature is still in its infancy.

Table 5: Mapping IoT technology context to location

\begin{tabular}{|c|c|c|c|c|c|c|c|c|c|}
\hline $\begin{array}{l}\text { Country } \\
\text { (N) }\end{array}$ & $* G$ & $\begin{array}{l}* \mathrm{P} \\
\mathrm{H}\end{array}$ & $\begin{array}{c}* \mathrm{~S} \\
\mathrm{D}\end{array}$ & $\begin{array}{l}* \mathrm{~S} \\
\mathrm{C}\end{array}$ & $\begin{array}{c}{ }^{*} \mathrm{R} \\
\mathrm{S}\end{array}$ & $\begin{array}{l}* \mathrm{~S} \\
\mathrm{M}\end{array}$ & $\begin{array}{l}* \mathrm{~S} \\
\mathrm{M}\end{array}$ & $\begin{array}{c}{ }^{*} \mathrm{H} \\
\mathrm{C}\end{array}$ & $\begin{array}{l}* \\
\mathrm{E} \\
\mathrm{T}\end{array}$ \\
\hline UK (2) & & (36) & & & & (47) & & & \\
\hline $\begin{array}{c}\text { South } \\
\text { Korea (4) }\end{array}$ & $\begin{array}{l}(20)(2 \\
3)\end{array}$ & (27) & & & & & & (32) & \\
\hline China (2) & & & & & & & & $(52)$ & $\begin{array}{l}\text { (2 } \\
1)\end{array}$ \\
\hline US (3) & (37) & & & & & $\begin{array}{l}34) \\
\text { (19) }\end{array}$ & & & \\
\hline $\begin{array}{c}\text { Taiwan } \\
\text { (4) }\end{array}$ & $\begin{array}{l}(39) \\
(22)(5 \\
3)\end{array}$ & & & & & (35) & & & \\
\hline India (3) & (28) & & (24) & & (41) & & & & \\
\hline $\begin{array}{c}\text { South } \\
\text { Africa (1) }\end{array}$ & & & & (40) & & & & & \\
\hline $\begin{array}{l}\text { Malaysia } \\
\text { (2) }\end{array}$ & (50) & & & (30) & & & & & \\
\hline $\begin{array}{c}\text { North } \\
\text { America } \\
(1)\end{array}$ & & & & & & & (43) & & \\
\hline $\begin{array}{l}\text { Thailand } \\
\text { (1) }\end{array}$ & (44) & & & & & & & & \\
\hline Turkey (1) & & & & & & & & (29) & \\
\hline $\operatorname{Iran}(1)$ & & & & (31) & & & & & \\
\hline $\begin{array}{l}\text { Indonesia } \\
\text { (2) }\end{array}$ & & & & & & $\begin{array}{l}(51) \\
(46)\end{array}$ & & & \\
\hline $\begin{array}{l}\text { Nether- } \\
\text { land(1) }\end{array}$ & & & & & & (45) & & & \\
\hline $\begin{array}{l}\text { Germany } \\
\text { (2) }\end{array}$ & & & & & & $\begin{array}{l}(48) \\
(49)\end{array}$ & & & \\
\hline $\begin{array}{c}\text { General } \\
\text { (2) }\end{array}$ & $\begin{array}{l}(25)(3 \\
8)\end{array}$ & & & & & & & & \\
\hline Total & 11 & 2 & 1 & 3 & 1 & 9 & 1 & 3 & 1 \\
\hline
\end{tabular}

*G: General service, *SH: Smart homes, *SD: Smart device, *SC: Smart cities, *RS: Retail system, *SM: Smart meters, *SMG: Smart microgrid, ${ }^{*} H C$ : Health care, ${ }^{*} E-T:$ E-Toll collection

The analysis of the usage stage of each technology revealed that majority of articles (19 articles) (see Table 6) targeted behavioral intention towards technology use, followed by articles that targeted continued intention ( 2 articles), articles dedicated to actual use (1 article), technology acceptance ( 1 article), attitude towards technology (1 article) and other behavior like technology support, challenges and human factors (4 articles).

Table 6: Usage stage or Intended behaviour toward technology

\begin{tabular}{|c|c|}
\hline Intended Behaviour (N) & Article \\
\hline Intention (24) & $(19-25,27-30,34-$ \\
& $38,41,43,44,46,47,49-51)$ \\
\hline Continued Intention (2) & $(22),(48)$ \\
\hline Actual Use (1) & $(52)$ \\
\hline
\end{tabular}

\begin{tabular}{|c|c|}
\hline Acceptance (2) & $(31,45)$ \\
\hline Attitude (1) & $(47)$ \\
\hline Others & $(34)(40)(39)(32)$ \\
\hline
\end{tabular}

In Table 7 , the findings of the analysis of the 32 articles are mapped out based on Internet of things (IoT) acceptance factors and the used research methods (i.e., Delphi Study (DS), Survey (SUR), Interviews (INT), and Conceptual Paper (CP) ). The table also provides the number of articles $(\mathrm{N})$ for every factor and research method used. Generally, the findings showed only few qualitative studies that used interviews have shed light on the IoT acceptance in comparison to quantitative studies that used surveys. As for the factors that influenced IoT acceptance, survey and conceptual articles have extensively examined them, but not in-depth studies.

Furthermore, 33 potential factors were culled from the articles to influence the IoT acceptance among individuals, with more than one factor revealed to affect such acceptance in majority of the articles. From the 33 factors, six constituted $51 \%$ of the mentioned factors, with usefulness being the top frequently examined factor (17 times), followed by ease of use (16 times), privacy ( 15 times), cost (12 times), social influence (12 times), and trust (8 times). Several other highlighted factors that influenced IoT adoption in the articles examined include enjoyment, behavioral control and attitude (7 times), security (5 times), performance expectancy, effort expectancy, interactivity and compatibility (4 times), benefits, risks, satisfaction, quality, media and control (3 times), coolness, subjective norm, knowledge, innovation, habit, safety, organizational image, triability and vulnerability (2 times). With regards to the least mentioned influential factors, they include value, technology awareness, facilitating conditions and environmental concerns, which were each mentioned only once.

Table 7: Identified factors by reviewed articles

\begin{tabular}{|c|c|c|c|c|}
\hline Factor & $\mathrm{CP}$ & SUR & DS & INT \\
\hline Usefulness (17) & (25) & $\begin{array}{l}(36)(21)(37)(22) \\
(24)(38)(41)(50) \\
(27)(44)(28)(51) \\
(54)(48)(49)\end{array}$ & $(52)$ & \\
\hline Ease of use (16) & (25) & $\begin{array}{l}(36)(20)(21)(37) \\
(24)(38)(41)(44) \\
(28)(29)(31)(51) \\
(48)(49)\end{array}$ & $(52)$ & \\
\hline Enjoyment (7) & & $\begin{array}{l}(20)(21)(22)(23) \\
(50)(27)(30)\end{array}$ & & \\
\hline Cost (12) & $\begin{array}{l}(25) \\
(39)\end{array}$ & $\begin{array}{l}(20)(22)(27)(30) \\
(51)(54)(45) \\
(46)(35)\end{array}$ & $(52)$ & \\
\hline Trust (8) & (25) & $\begin{array}{l}(21)(23)(41)(50) \\
(30)(31)(54)\end{array}$ & & \\
\hline $\begin{array}{l}\text { Social Influence } \\
\text { (12) }\end{array}$ & (25) & $\begin{array}{l}(21)(38)(50)(30) \\
(31)(51)(45)(46) \\
(35)(20)\end{array}$ & $(52)$ & \\
\hline $\begin{array}{l}\text { Behavioral Con- } \\
\text { trol (7) }\end{array}$ & & $\begin{array}{l}(21)(24)(41)(50) \\
(27)(31)(48)\end{array}$ & & \\
\hline Coolness (2) & & (37) & & (32) \\
\hline Privacy (15) & $\begin{array}{l}(25) \\
(39)\end{array}$ & $\begin{array}{l}(22)(38)(53)(29) \\
(51)(54)(45)(19) \\
(48)(36)(50)(27)\end{array}$ & $(52)$ & \\
\hline Value (1) & & (22) & & \\
\hline Attitude (7) & & $\begin{array}{l}(24)(53)(41) \\
(27)(51)(48)(49)\end{array}$ & & \\
\hline $\begin{array}{l}\text { Subjective Norm } \\
\text { (2) }\end{array}$ & & $(24)(41)$ & & \\
\hline Knowledge (2) & $(25)$ & (36) & & \\
\hline Security (5) & $\begin{array}{l}(25) \\
(39)\end{array}$ & $(45)(46)$ & (52) & \\
\hline Benefits (3) & & $(53)(29)(31)$ & & \\
\hline $\begin{array}{l}\text { Performance } \\
\text { Expectancy (4) }\end{array}$ & & $(43)(30)(45)(46)$ & & \\
\hline $\begin{array}{l}\text { Effort Expectan- } \\
\text { cy (4) }\end{array}$ & & $(43)(30)(45)(46)$ & & \\
\hline
\end{tabular}




\begin{tabular}{|l|l|l|l|l|}
\hline Innovation (2) & & $(43)$ & $(52)$ & \\
\hline Interactivity (4) & & $(36)(45)(35)$ & $(52)$ & \\
\hline $\begin{array}{l}\text { Compatibility } \\
\text { (4) }\end{array}$ & $(27)(29)(45)$ & $(52)$ & \\
\hline Habit (2) & $(30)(54)$ & & \\
\hline Risks (3) & $(51)(45)(46)$ & & \\
\hline Safety (2) & $(51)(44)$ & & \\
\hline Satisfaction (3) & $(51)(31)$ & & $(32)$ \\
\hline $\begin{array}{l}\text { Technology } \\
\text { Awareness (1) }\end{array}$ & $(45)$ & & \\
\hline $\begin{array}{l}\text { Facilitating Con- } \\
\text { dition (1) }\end{array}$ & $(46)$ & & \\
\hline $\begin{array}{l}\text { Environment } \\
\text { Concerns (1) }\end{array}$ & $(47)$ & & & \\
\hline Quality (3) & & $(20)(23)$ & & $(32)$ \\
\hline Media (3) & $(20)(45)(35)$ & & \\
\hline Control (3) & $(45)(19)(49)$ & & \\
\hline $\begin{array}{l}\text { Organization } \\
\text { Image (2) }\end{array}$ & $(45)(29)$ & & \\
\hline Trialability (2) & & $(45)(29)$ & $(35)(29)$ & \\
\hline Vulnerability (2) & & 26 & & \\
\hline $\begin{array}{l}\text { Total (without } \\
\text { repetitions) }\end{array}$ & 3 & & & \\
\hline
\end{tabular}

\section{Discussion and Future Directions}

A total of thirty-two (32) articles were reviewed in this study to determine the current state of the IS research, specifically regarding IoT acceptance among individuals. The review yielded findings that can be discussed based on three perspectives namely theoretical (in terms of theories and models), methodological (in terms of research methods used) and empirical (in terms of IoT acceptance factors). Generally, the findings showed that only a single IS journal article was dedicated to providing insight into the IoT acceptance. On the other hand, non-IS journal and conference articles dominated the examination of the IoT phenomenon. The findings revealed that an IoT acceptance research agenda is structured based on the direct examination of theoretical, methodological and empirical research. These perspectives are discussed in detail individually in the following paragraphs.

\subsection{Theoretical Perspective}

The first perspective is the theoretical one, and on this basis, dominating articles made use of technology acceptance model (TAM) as well as general concepts, with only a few that applied the other acceptance and adoption theories ( e.g. UTAUT) to study IoT phenomenon and they did not extend to cover all IoTbased technologies and services. Yet, there is a need for applying other related theories to other IoT-based technologies and services, to gain a comprehensive understanding regarding IoT acceptance. The existing IoT-based technologies and services are various, they have common characteristics but different functions and different context, thus different factors may influence its acceptance. In fact IoT have transformed the perceptions among users on technology use and interaction. It involved a set of connected sensors and devices that directly send data reflecting actions and movements around user. Therefore, there is a need to deeply understand how these specific technologies and services work and interact with objects within internet environment, and then apply related acceptance factors from different fields (e.g. psychology, technological, and personal) that fit studying the acceptance of IoT innovation, to gain more insights regarding factors influencing use of IoTbased technologies and services. As a consequence of this review, interesting insights are provided to the empirical examination attempts of researchers including the factors affecting the acceptance of IoT-based technologies and services, and the way service providers and developers can create strategies to tackle the factors.

\subsection{Methodological Perspective}

The second perspective is the methodological one and according to the obtained findings, there is lack of in-depth field and case studies dedicated to the acceptance of IoT in comparison to those that focused on individual's use and acceptance of IoT that are mostly conducted through survey studies. In regards to this type of research, some theoretical studies have been left untested; for example, a study brought forward a theory of IoT acceptance model in the telecommunication context, but the model has not been empirically tested (25). As such, quality researcher has to be conducted to examine further issues and empirically test prior theoretical developments in the area. This leads to the questions as to "why individuals accept IoT-based technologies and services despite the potential risks?", "why individuals refrain from accepting IoT-based technologies and services despite the potential advantages?" Future studies need to tackle these questions using qualitative case studies in various contexts, countries and industries to further explore the factors that influence the acceptance of IoT. Most of the articles reviewed in this study examined the IoT factors in general and while several articles investigated smart meter technology, most of them focused on the smart meters technology as a stand-alone technology not considering it under IoT environment. This stresses the need to conduct interpretive case studies to examine each IoT-based technologies and services, like smart homes, smart devices, smart cities and healthcare. This caliber of studies would contribute to both practical and academic. The review also highlights the requirement to conduct longitudinal studies for the assessment of the influence of IoT-based technologies and services use on the user and the service provider.

\subsection{Empirical Perspective}

Lastly, the review shows that IoT acceptance factors did not garner enough attention from empirical research that explore the challenges faced in each factor and the way the service provider and developers can address the challenges of using IoT-based technologies and services. In this regard, risks form a major issue among IoT users, particularly when it comes to privacy and this underlines the need for government to establish privacy protection rules when using IoT-based technologies and services. Such rules exist in developed countries but in the developing ones, a regulatory framework is still lacking that could be used to ensure data privacy during IoT use. This lays emphasis on the need to explore IoT acceptance in the context of developing countries and to benchmark developed countries lessons to the developing ones and vice versa. Such investigation should also explore the needs, concerns, and perceptions of consumers when using various IoTbased technologies and services and their attributes for the purpose of establishing corresponding rules.

Finally, the context-based behaviors/factors (e.g., healthcare behaviors, electricity saving behaviors, and safety behaviors) have a significant influence on the acceptance and use of technologies among individuals but this review indicated that this issue received less attention from researchers. The need thus exist to determine related behavior and factors for each context and examine their effect on IoT-based technologies and services acceptance.

\section{Conclusion}

This study conducted a systematic review of literature dedicated to the IoT-based technologies and services acceptance among individuals. Accordingly, the study identified the present contributions of IS research when it comes to IoT and determined the examined issues and contributions of researches of this caliber. The reviewed articles were classified based on their findings and the avenues and implications were divided based on theories adopted, used research methods, and factors examined. Aside from the 
issues touched upon in the articles, there are several issues that have yet to be examined by IS studies and thus, this study recommended future avenues to consider based on the findings obtained. With regards to the limitations, this study conducted a review of the academic articles obtained from only five literature databases, without considering white papers, magazine articles, and other databases of scholarly works. Articles obtained from a forward and backward search were also excluded although their inclusion would assist in encapsulating more issues related to IoT acceptance among individuals. Another limitation relates to the search criterion that was confined to the article titles - if abstracts were included, in-depth insights may have been unearthed. In relation to this, the search phrases were limited, which may have inadvertently excluded articles of acceptance of IoT-based technologies and services that contained equally important phrases like smart devices, smart homes and smart cities.

\section{References}

[1] ROPER P. Market potential of US $\$ 731 \mathrm{~b}$ in connected living by 2020: Frost \& Sullivan. Marketing [Internet]. 2014; Available from: https://www.marketingmag.com.au/news-c/market-potential-ofus731b-in-connected-living-by-2020-frost-sullivan/

[2] Daniel Castro JN\& AM. How Is the Federal Government Using the Internet of Things? [Internet]. Center of Data Innovation ; 2016 Available from: http://www2.datainnovation.org/2016-federaliot.pdf

[3] Hoover M. Study: IoT adoption still slow for government agencies [Internet]. INTERNET OF THINGS. Washington Technology; $2016 . \quad$ Available from https://washingtontechnology.com/articles/2016/07/26/agenciesslow-iot-adoption.aspx

[4] RedHat. The One-Word Description of the Enterprise Internet-ofThings: Deliberate [Internet]. RED HAT BLOG. RedHat; 2015. Available from: https://www.redhat.com/en/about/blog/one-worddescription-enterprise-internet-things-deliberate

[5] Bussu S. The Internet of Things: the case for public voice Sciencewise evaluation. UK: Sciencewise; 2014.

[6] Alkawsi GA, BTE. ALI N, ALGHUSHAMI A. TOWARD UNDERSTANDING INDIVI DUALS' ACCEPTANCE OF INTERNET OF THINGS - BASED SERVICES : DEVELOPING AN INSTRUMENT TO MEASURE

[7] Atzori L, Iera A, Morabito G. The internet of things: A survey. Comput networks. 2010;54(15):2787-805.

[8] 8Gubbi J, Buyya R, Marusic S, Palaniswami M. Internet of Things (IoT): A vision, architectural elements, and future directions. Futur Gener Comput Syst. 2013;29(7):1645-60.

[9] Kranz M, Holleis P, Schmidt A. Embedded interaction: Interacting with the internet of things. IEEE Internet Comput. 2010;14(2):4653.

[10] Miorandi D, Sicari S, De Pellegrini F, Chlamtac I. Internet of things: Vision, applications and research challenges. Ad Hoc Networks. 2012;10(7):1497-516.

[11] Tan L, Wang N. Future internet: The internet of things. In: 2010 3rd International Conference on Advanced Computer Theory and Engineering (ICACTE). IEEE; 2010. p. V5-376-V5-380.

[12] Brous P, Janssen M. A Systematic Review of Impediments Blocking Internet of Things Adoption by Governments. In: Janssen M, Mäntymäki M, Hidders J, Klievink B, Lamersdorf W, van Loenen B, et al., editors. Open and Big Data Management and Innovation : 14th IFIP WG 611 Conference on e-Business, e-Services, and eSociety, I3E 2015, Delft, The Netherlands, October 13-15, 2015, Proceedings [Internet]. Cham: Springer International Publishing; 2015. p. 81-94. Available from: http://dx.doi.org/10.1007/978-3319-25013-7_7

[13] Riggins FJ, Wamba SF. Research Directions on the Adoption, Usage, and Impact of the Internet of Things through the Use of Big Data Analytics. In: System Sciences (HICSS), 2015 48th Hawaii International Conference on. 2015. p. 1531-40.

[14] YAN B, XIANG W, SHI P. Analysis of influence factors for adoption of internet of things in agricultural supply chain. Soft Sci. 2013;3:7.

[15] Okoli C, Schabram K. A guide to conducting a systematic literature review of information systems research. Sprouts Work Pap Inf Syst. 2010;10:26.
[16] Yang H, Tate M. A descriptive literature review and classification of cloud computing research. Commun Assoc Inf Syst. 2012:31(2):35-60

[17] Webster J, Watson RT. Analyzing the past to prepare for the future: Writing a. MIS Q. 2002;26(2):13-23.

[18] 18. Williams MD, Dwivedi YK, Lal B, Schwarz A. Contemporary trends and issues in IT adoption and diffusion research. J Inf Technol. 2009;24(1):1-10.

[19] Warkentin M, Goel S, Menard P. Shared benefits and information privacy: What determines smart meter technology adoption? J Assoc Inf Syst [Internet]. 2017;18(11):758-86. Available from: https://www.scopus.com/inward/record.uri?eid=2-s2.085037379191\&partnerID=40\&md5=2fa98d530590dc9a8f6d7483a de6c 227

[20] Hong HGHG. Measurement Framework for the Acceptance of Internet of Things Product. Indian J Sci Technol. 2016;9(46).

[21] Gao L, Bai X. A unified perspective on the factors influencing consumer acceptance of internet of things technology. Asia Pacific J Mark Logist [Internet]. 2014;26(2):211-31. Available from: http://www.emeraldinsight.com/doi/abs/10.1108/APJML-06-20130061

[22] Hsu C-L, Lin JC-C. Exploring Factors Affecting the Adoption of Internet of Things Services. J Comput Inf Syst [Internet]. 2016;0(0):1-9. Available from: https://www.tandfonline.com/doi/full/10.1080/08874417.2016.1186 524

[23] Lee W-J, Chong S-S. A dual-factor model to explain the future adoption of smart internet of things service and its implications. Int J Softw Eng its Appl. 2016;10(11).

[24] Mital M, Chang V, Choudhary P, Pani A, Sun Z. Adoption of cloud based Internet of Things in India: A multiple theory perspective. Int J Inf Manage [Internet]. 2016 Mar; Available from: http://linkinghub.elsevier.com/retrieve/pii/S0268401216301104

[25] Al-Momani AM, Mahmoud MA, Sharifuddin M. Modeling the adoption of internet of things services: A conceptual framework. IJAR. 2016;2(5):361-7.

[26] Hsu C-L, Lin JC-C. An empirical examination of consumer adoption of Internet of Things services: Network externalities and concern for information privacy perspectives. Comput Human Behav. 2016;62:516-27.

[27] Park E, Cho Y, Han J, Kwon SJ. Comprehensive Approaches to User Acceptance of Internet of Things in a Smart Home Environment. IEEE Internet Things J. 2017;4(6):2342-50.

[28] Singh G, Gaur L, Ramakrishnan R. Internet of things - technology adoption model in India. Pertanika J Sci Technol [Internet]. 2017;25(3):835-46. Available from: https://www.scopus.com/inward/record.uri?eid=2-s2.085021067105\&partnerID=40\&md5=adb5bf3137475bcc9a9a1f5 1e9 b85233

[29] Karahoca A, Karahoca D, Aksöz M. Examining intention to adopt to internet of things in healthcare technology products [Internet]. Kybernetes. 2017. Available from: https://www.scopus.com/inward/record.uri?eid=2-s2.0$85037349187 \&$ doi $=10.1108 \% 2$ FK-02-20170045\&partnerID $=40 \& \mathrm{md} 5=$ ce $41079 \mathrm{~b} 9833 \mathrm{~d} 8723 \mathrm{f} 64 \mathrm{f} 10662521 \mathrm{bfe}$

[30] Leong GW, Ping TA, Muthuveloo R. Antecedents of Behavioural Intention to Adopt Internet of Things in the Context of Smart City in Malaysia. Glob Bus Manag Res. 2017;9.

[31] M. Saeidi, A. Houshang DTV. ASSESSING OF THE EFFECTIVE FACTORS IN THE ACCEPTANCE OF INTERNET OF THINGS TECHNOLOGY IN SMART BUILDINGS (CASE STUDY: CUSTOMER OF ACTIVE COMPANIES IN SMART BUILDINGS IN TEHRAN). J Fundam Appl Sci [Internet]. 2017 Feb;22(1):3. Available from: https://scihub.tw/http://jfas.info/index.php/jfas/article/view/2720

[32] Shin D, Hwang Y. Integrated acceptance and sustainability evaluation of Internet of Medical Things: A dual-level analysis. Internet Res. 2017;27(5):1227-54.

[33] Chou J-S, Gusti Ayu Novi Yutami I. Smart meter adoption and deployment strategy for residential buildings in Indonesia. Appl Energy. 2014;128:336-49.

[34] Chen C, Xu X, Arpan L. Between the technology acceptance model and sustainable energy technology acceptance model: Investigating smart meter acceptance in the United States. Energy Res Soc Sci [Internet]. 2017 [cited 2018 Mar 26];25:93-104. Available from: https://www.sciencedirect.com/science?_ob=ArticleListURL\&_met hod=list\&_ArticleListID =- 
$1254965192 \&$ sort $=\mathrm{r} \&$ st $=5 \& \mathrm{md} 5=6523 \mathrm{aed} 5 \mathrm{a} 11 \mathrm{df} 352 \mathrm{~b} 10077 \mathrm{a} 99$ 2 fd6075\&searchtype $=\mathrm{a}$

[35] Chen K-Y, Yeh C-F. Factors affecting adoption of smart meters in the post-Fukushima era in Taiwan: an extended protection motivation theory perspective. Behav Inf Technol [Internet]. 2017 Sep 2;36(9):955-69. Available from: https://doi.org/10.1080/0144929X.2017.1317363

[36] Coughlan T, Brown M, Mortier R, Houghton RJJ, Goulden M, Lawson G. Exploring Acceptance and Consequences of the Internet of Things in the Home. In: Green Computing and Communications (GreenCom), 2012 IEEE International Conference on. 2012. p. 148-55.

[37] Fan Y. From Innovators to Power Users: The Role Of Power Usage in Driving Adoption Of the Internet Of Things (IoT). 2016;

[38] Attié E, Meyer-Waarden L. A theoretical model incorporating social influence and cognitive processes to explain the adoption of the internet of things and smart connected objects [Internet]. 2016. Available http://econpapers.repec.org/RePEc:hal:journl:halshs-01406423

[39] Luthra S, Garg D, Mangla SK, Singh Berwal YP. Analyzing challenges to Internet of Things (IoT) adoption and diffusion: An Indian context. Procedia Comput Sci. 2018;125:733-9.

[40] Luqman A, Belle JP Van. Analysis of human factors to the adoption of Internet of Things-based services in informal settlements in Cape Town. In: 2017 1st International Conference on Next Generation Computing Applications (NextComp). 2017. p. 61-7.

[41] Patil K. Retail adoption of Internet of Things: Applying TAM model. In: 2016 International Conference on Computing, Analytics and Security Trends (CAST). 2016. p. 404-9.

[42] Zhai Y, Liu Y, Zhou T, Shen P. Identification of key factors in health service adoption based on Internet of things and empirical test. In: 2017 29th Chinese Control And Decision Conference (CCDC). 2017. p. 7257-62.

[43] Westerlund M, Rajala R, Kavandi H, Rajahonka M, Leminen S. Supply chain reactions to the rise of the internet of things: Reseller adoption of smart microgrid solutions. In: Proceedings of the International Conference on Electronic Business (ICEB). 2015.

[44] Saenphon T. An analysis of the technology acceptance model in understanding university student's awareness to using internet of things. In: ACM International Conference Proceeding Series [Internet]. 2017. p. 61-4. Available from: https://www.scopus.com/inward/record.uri?eid=2-s2.0$85028768732 \&$ doi $=10.1145 \% 2 \mathrm{~F} 3108421.3108432 \&$ partnerID $=40$ \&md5=6921b9430fcec4d5dda97dee082333a7

[45] Alabdulkarim A, Lukszo Z, Fens TW. Acceptance of ICT Intensive Socio-Technical Infrastructure Systems: Smart metering Case in the Netherlands Layla. 2012;(June):399-404.

[46] Indrawati, Tohir LM. Predicting smart metering acceptance by residential consumers: An Indonesian perspective. 2016 4th Int Conf Inf Commun Technol ICoICT 2016. 2016;4(c).

[47] Sim J, Cho D. A Multiyear Study of Smart Meter Adoption: Empirical Evidence from the United Kingdom. In: ICIS 2017: Transforming Society with Digital Innovation [Internet]. 2018. Available from: https://www.scopus.com/inward/record.uri?eid=2-s2.0$85041743542 \&$ partnerID $=40 \&$ md5=b0bb0a7f9a3eeeb97001c983bf $1 \mathrm{cbbc} 8$

[48] Wunderlich P, Veit D, Sarker S. Examination of the determinants of smart meter adoption: An user perspective. In: International Conference on Information Systems, ICIS 2012 [Internet]. 2012. p. $1941-57$. Available

from: https://www.scopus.com/inward/record.uri?eid=2-s2.0$84886483376 \&$ partnerID $=40 \& \mathrm{md} 5=963657 \mathrm{c} 86 \mathrm{bea} 11961 \mathrm{c} 3 \mathrm{~b} 17 \mathrm{ecd}$ c3ea6de

[49] Kranz J, Gallenkamp J, Picot A. Power control to the people? Private consumers' acceptance of smart meters. In: 18th European Conference on Information Systems, ECIS 2010 [Internet]. 2010. Available from: https://www.scopus.com/inward/record.uri?eid=2s2.084870642506\&partnerID=40\&md5=78374b5d94389cfe5f06e9a3f0 $24 \mathrm{c} 3 \mathrm{e} 4$

[50] Liew CS, Ang JM, Goh YT, Koh WK, Tan SY, Teh RY. Factors Influencing Consumer Acceptance of Internet of Things Technology. Handb Res Leveraging Consum Psychol Eff Cust Engagem. 2016;186.

[51] Chou J-S, Yutami GAN. Smart meter adoption and deployment strategy for residential buildings in Indonesia. Appl Energy [Internet]. 2014;128:336-49. Available from: https://www.scopus.com/inward/record.uri?eid=2-s2.0-
84901202816\&doi=10.1016\%2Fj.apenergy.2014.04.083\&partnerI $\mathrm{D}=40 \& \mathrm{md} 5=\mathrm{db} 3 \mathrm{a} 054 \mathrm{a} 5 \mathrm{e} 2 \mathrm{ad} 8 \mathrm{a} 62 \mathrm{ede} 6 \mathrm{~b} 290 \mathrm{e} 6 \mathrm{da} 2 \mathrm{~d} 1$

[52] Zhai Y, Liu Y, Zhou T, Shen P. Identification of key factors in health service adoption based on Internet of things and empirical test. In: 2017 29th Chinese Control And Decision Conference (CCDC). 2017. p. 7257-62.

[53] Hsu C-WC-W, Yeh C-CC-C. Understanding the factors affecting the adoption of the Internet of Things. Technol Anal Strateg Manag [Internet]. 2016;0(0):1-14. Available from: https://www.tandfonline.com/doi/full/10.1080/09537325.2016.1269 160

[54] Chen C-F, Xu X, Arpan L. Between the technology acceptance model and sustainable energy technology acceptance model: Investigating smart meter acceptance in the United States. Energy Res Soc Sci [Internet]. 2017;25:93-104. Available from: https://www.scopus.com/inward/record.uri?eid=2-s2.0$85009152778 \&$ doi $=10.1016 \% 2 \mathrm{Fj}$. erss.2016.12.011\&partnerID=40 \&md5 $=5$ fc81439cb0864b0cafea139bb3d330d 